\title{
Hubungan Kualitas Pelayanan Kesehatan Posyandu Terhadap Frekuensi Kunjungan Ibu Balita Di Posyandu VI Flamboyan Lingkungan Kiring Kelurahan Gedongombo Kecamatan Semanding
}

\author{
${ }^{1}$ Dyah Pitaloka, ${ }^{2}$ Tiara Putri Ryandini \\ ${ }^{1,2}$ STIKES Nahdlatul Ulama Tuban \\ Email: dyahpitaloka385@gmail.com
}

\begin{abstract}
ABSTRAK
Faktor-faktor yang mempengaruhi penurunan frekuensi kunjungan adalah rendahnya minat masyarakat untuk mengikuti kegiatan di Posyandu dan diperparah dengan kurangnya kemampuan petugas kesehatan dalam meningkatkan kualitas pelayanan kesehatan Posyandu. Tujuan penelitian ini adalah untuk mengetahui hubungan kualitas pelayanan kesehatan posyandu terhadap frekuensi kunjungan ibu balita di posyandu VI Flamboyan Lingkungan Kiring Kelurahan Gedongombo Kecamatan Semanding.

Desain penelitian ini adalah analitik observasional dengan pendekatan waktu cross sectional dan melibatkan 36 responden, yang diambil dengan teknik simple random sampling. Metode pengambilan data menggunakan kuesioner dan observasi KMS balita.

Analisis dalam penelitian ini menggunakan uji koefisien kontigensi diperoleh $\rho=0,016$ yang berarti terdapat hubungan antara pelayanan posyandu dengan kunjungan ibu balita. Diharapkan petugas posyandu memotivasi ibu balita tentang manfaat datang di posyandu sehingga ibu balita rutin datang di posyandu setiap bulannya.
\end{abstract}

Kata kunci: Posyandu, kualitas pelayanan kesehatan, frekuensi kunjungan.

\section{PENDAHULUAN}

Pembangunan

Kesehatan dilaksanakan secara bersama-sama oleh pemerintah dan masyarakat. Peran serta masyarakat dalam berbagai upaya pembangunan kesehatan antara lain dapat dilihat dari Upaya Kesehatan Bersumberdaya Masyarakat (UKBM) yang berkembang dengan pesat baik dalam bentuk Pos Pelayanan Terpadu (Posyandu), Pos Obat Desa (POD) maupun Dana Sehat. Rasio Posyandu terhadap desa pada tahun 1999 sudah melebihi $90 \%$, artinya hampir setiap desa telah mempunyai sebuah Posyandu yang berfungsi untuk mendekatkan pelayanan kesehatan pada masyarakat (Wijayanti, 2009).
Posyandu menjadi ujung tombak perbaikan gizi anak. Posyandu diasumsikan sebagai salah satu pendekatan yang tepat untuk menurunkan angka kematian dan kesakitan balita serta dapat meningkatkan status gizi balita (Adisasmito, 2008). Posyandu setiap bulannya melakukan kegiatan penimbangan berat badan balita dan hasilnya dicatat dalam buku KIA atau KMS. Catatan KIA bertujuan untuk mengetahui hasil penimbangan apakah garis pertumbuhannya naik, tidak naik atau di bawah garis merah (BGM). Penimbangan anak balita setiap bulan dapat diketahui kecenderungan status gizi seorang anak (Sulistyorini, 2010). Posyandu 
memiliki lima kegiatan pokok yaitu keluarga berencana $(\mathrm{KB})$, kesehatan ibu dan anak (KIA), pemantauan gizi anak, imunisasi, dan penanggulangan diare. Semua program posyandu memiliki peran yang penting dalam menurunkan angka kematian bayi (AKB).

Kehadiran berarti serangkaian keteraturan kegiatan atau proses yang terjadi beberapa kali atau lebih. Kehadiran ibu balita posyandu berarti datangnya ibu balita di posyandu secara teratur untuk mendapatkan pelayanan seperti pelayanan kesehatan ibu dan anak, keluarga berencana, imunisasi, pemantauan gizi anak, pencegahan dan penanggulangan diare dan sebagainya. Cakupan balita di posyandu $(\mathrm{D} / \mathrm{S})$ merupakan indikator yang berkaitan dengan pelayanan cakupan gizi pada balita, cakupan pelayanan kesehatan dasar khusunya imunisasi serta prevalensi gizi kurang. Sedangkan di Lingkungan Kiring banyak ibu balita yang tidak rutin datang mengikuti kegiatan di posyandu, dilihat dari data kunjungan posyandu ibu balita yang mengikuti kegiatan di posyandu pada bulan desember tahun 2015 hanya 53\% dari total balita yang terdaftar di posyandu VI Flamboyan Lingkungan Kiring.

Survei awal yang dilakukan peneliti melalui wawancara didapatkan dari 10 ibu balita yang rutin datang mengikuti kegiatan di posyandu hanya $20 \%$ dan $80 \%$ tidak rutin datang mengikuti kegiatan di posyandu. Dari $80 \%$ responden yang tidak rutin datang mengikuti kegiatan di posyandu, $40 \%$ mengatakan kurang terhadap pelayanan yang diberikan karena kurang maksimalnya pelayanan terutama pada meja ke empat yaitu penyuluhan dan pelayanan gizi serta meja ke lima yaitu imunisasi, $10 \%$ mengatakan jarak rumah yang jauh, 20\% mengatakan bekerja dan 10\% mengatakan balita tertidur sehingga tidak datang melakukan penimbangan di posyandu.

Apabila perilaku berkunjung ke Posyandu semakin berkurang maka dapat mengakibatkan tahap tumbuh kembang anak akan terganggu, status gizi anak tidak terpantau dengan baik, dan tujuan dari Posyandu itu sendiri juga tidak akan tercapai sehingga sampai menyebabkan angka kecacatan, kematian, serta kesakitan balita akan meningkat.

Masalah-masalah kesehatan seperti gizi dipengaruhi oleh rendahnya pemanfaatan dan kualitas pelayanan Posyandu. Kegiatan Posyandu hanya terkesan sebagai kegiatan rutinitas penimbangan balita, dan pemberian imunisasi, sementara penggerakan aksi masyarakat dan komunikasi hampir tidak ada. Sehingga masyarakat belum sepenuhnya menjadikan Posyandu sebagai pusat kegiatan kesehatan masyarakat (Dinkes Bone, 2008). Hal ini disebabkan karena kurangnya kemampuan kader kesehatan dalam mengelola dan kualitas pelayanan kesehatan Posyandu.

Faktor-faktor yang dapat mempengaruhi ketidakaktifan ibu balita sehingga tidak berkunjung ke posyandu antara lain: faktor keluarga meliputi tingkat pendidikan, tingkat pengetahuan, umur balita, kepercayaan, status pekerjaan, tingkat pendapatan, dan sikap (Notoatmodjo, 2003). Faktor lingkungan meliputi keterjangkauan (letak dan jarak), sarana dan fasilitas posyandu (Hikmawati, 2008). Faktor kualitas pelayanan kesehatan posyandu meliputi kompetensi teknis, akses 
terhadap pelayanan, efektifitas, afisien, kontinuitas, keamanan, hubungan antar manusia, kenyamanan (Pohan, 2007). Sedangkan menurut Wijono (2000) kualitas dipengaruhi oleh struktur, proses, dan outcome.

Berbagai kegiatan dan program posyandu balita sangat baik dan banyak memberikan manfaat bagi masyarakat di posyandu. Seharusnya ibu balita berupaya memanfaatkan adanya posyandu tersebut sebaik mungkin, agar kesehatan balita dapat terpelihara dan terpantau secara optimal. Balita yang tidak rutin dalam memanfaatkan pelayanan kesehatan di posyandu, maka kondisi kesehatan balita tidak dapat terpantau dengan baik. Penyuluhan dan sosialisasi tentang pengertian, tujuan serta manfaat posyandu balita perlu terus ditingkatkan dan perlu mendapat dukungan dari berbagai pihak, baik keluarga, kader, petugas kesehatan pemerintah maupun masyarakat itu sendiri.

Melihat jumlah kunjungan Posyandu balita masih kurang, maka penulis tertarik melakukan penelitian mengenai "Hubungan kualitas pelayanan kesehatan Posyandu dengan frekuensi kunjungan ibu balita di Posyandu VI Flamboyan Lingkungan Kiring Kelurahan Gedongombo Kecamatan Semanding".

\section{BAHAN DAN METODE}

Penelitian ini menggunakan desain penelitian analitik observasional, dengan rancangan cross sectional. Populasi dalam penelitian ini adalah semua ibu balita yang datang di posyandu VI Flamboyan pada bulan April 2015 sampai Maret 2019 yang sesuai dengan kriteria inklusi sebanyak 40 responden, dengan besar sampel penelitian 36 responden yang ditentukan menggunakan teknik simple random sampling. Variabel independen dalam penelitian ini adalah kualitas pelayanan kesehatan posyandu, sedangkan variabel dependen adalah freskuensi kunjungan ibu balita. Instrumen yang digunakan dalam pengumpulan data berupa kuesioner dan lembar observasi buku KMS balita. Analisis penelitian menggunakan uji koefisien kontingensi dengan tingkat kemaknaan $\alpha=0,05$.

\section{HASIL}

\section{Data Umum}

1. Umur Responden

Tabel 1 Distribusi Responden Berdasarkan Umur ibu balita di Posyandu VI Flamboyan Lingkungan Kiring Kelurahan Gedongombo Kecamatan Semanding Tahun 2019

\begin{tabular}{|c|c|c|c|}
\hline No & Umur & $f$ & $\begin{array}{c}\text { Prosentase } \\
(\%)\end{array}$ \\
\hline 1 & $\begin{array}{l}<20 \\
\text { Tahun }\end{array}$ & 1 & 2,8 \\
\hline 2 & $\begin{array}{l}20-35 \\
\text { Tahun }\end{array}$ & 33 & 91,7 \\
\hline \multirow[t]{2}{*}{3} & $\begin{array}{c}>35 \\
\text { Tahun }\end{array}$ & 2 & 5,6 \\
\hline & Jumlah & 36 & 100 \\
\hline
\end{tabular}

Tabel 1 diatas dapat diketahui bahwa sebagian besar responden berumur antara 20-35 tahun sebanyak 33 orang $(91,7 \%)$, dan sebagian kecil responden berumur $<20$ tahun sebanyak 1 orang $(2,8 \%)$. 
2. Pendidikan Responden

Tabel 2 Distribusi Responden

Berdasarkan Pendidikan ibu balita di posyandu VI Flamboyan Lingkungan Kiring Kelurahan Gedongombo Kecamatan Semanding

\begin{tabular}{lccc}
\hline No & Pendidikan & $\boldsymbol{f}$ & $\begin{array}{c}\text { Prosentase } \\
(\boldsymbol{\%})\end{array}$ \\
\hline 1 & SD & 18 & 50 \\
2 & SMP & 4 & 11,1 \\
3 & SMA & 10 & 27,8 \\
4 & Pendidikan & 4 & 11,1 \\
& Tinggi & & \\
\hline & Jumlah & 36 & 100
\end{tabular}

Tabel 2 diatas dapat diketahui bahwa sebagian besar responden berpendidikan SD sebanyak 18 orang (50\%) dan sebagian kecil responden berpendidikan SMP dan Pendidikan Tinggi sebanyak 4 orang $(11,1 \%)$.

3. Pekerjaan

Tabel 3 Distribusi Responden Berdasarkan Pekerjaan ibu balita di posyandu VI Flamboyan Lingkungan Kiring Kelurahan Gedongombo Kecamatan Semanding

\begin{tabular}{|c|c|c|c|}
\hline No & Pekerjaan & $f$ & $\begin{array}{c}\text { Prosentase } \\
(\%)\end{array}$ \\
\hline 1 & $\begin{array}{c}\text { Ibu Rumah } \\
\text { Tangga }\end{array}$ & 10 & 27,8 \\
\hline 2 & Petani & 6 & 16,7 \\
\hline 3 & Wiraswasta & 11 & 30,6 \\
\hline 4 & Buruh & 7 & 19,4 \\
\hline \multirow[t]{2}{*}{5} & PNS & 2 & 5,6 \\
\hline & Jumlah & 36 & 100 \\
\hline
\end{tabular}

Tabel 3 diatas dapat diketahui bahwa sebagian besar responden bekerja sebagai wiraswasta sebanyak 11 orang $(30,6 \%)$ dan sebagian kecil bekerja sebagai PNS 2 orang $(5,6 \%)$.

\section{Jarak Rumah}

\section{Tabel 4 Distribusi Responden Berdasarkan Jarak Rumah Dengan Posyandu di posyandu VI Flamboyan Lingkungan Kiring Kelurahan Gedongombo Kecamatan Semanding}

\begin{tabular}{cccc}
\hline No & $\begin{array}{c}\text { Jarak } \\
\text { Rumah }\end{array}$ & $\boldsymbol{f}$ & Prosentase (\%) \\
\hline \multirow{2}{*}{1} & Sangat & 17 & 47,2 \\
& Dekat & & 33,3 \\
2 & Dekat & 12 & 13,9 \\
3 & Sedang & 5 & 5,6 \\
4 & Jauh & 2 & 100 \\
\hline & Jumlah & 36 & \\
\hline
\end{tabular}

Tabel 4 diatas dapat diketahui bahwa sebagian besar responden jarak rumah dengan posyandu sangat dekat sebanyak 17 orang $(47,2 \%)$ dan sebagian kecil responden jarak rumah dengan posyandu jauh sebanyak 2 orang $(5,6 \%)$.

\section{Data Khusus}

1. Pelayanan posyandu di Posyandu VI Flamboyan Lingkungan Kiring Kelurahan Gedongombo Kecamatan Semanding Tahun 2019

Tabel 5 Distribusi Kualitas Pelayanan Posyandu Di Posyandu VI Flamboyan Lingkungan Kiring Kelurahan Gedongombo Kecamatan Semanding Tahun 2019

\begin{tabular}{cccc}
\hline No & $\begin{array}{c}\text { Pelayanan } \\
\text { Posyandu }\end{array}$ & $\boldsymbol{f}$ & $\begin{array}{c}\text { Prosentase } \\
(\boldsymbol{\%})\end{array}$ \\
\hline 1 & Kurang & 5 & 13,9 \\
2 & Cukup & 24 & 66,7 \\
3 & Baik & 7 & 19,4 \\
\hline & Jumlah & 36 & 100 \\
\hline
\end{tabular}

Tabel 5 diatas menunjukkan bahwa sebagian besar responden 
sebanyak 24 orang $(66,7 \%)$ berpendapat bahwa pelayanan posyandu yang diberikan cukup, setengah responden sebanyak 7 orang $(19,4 \%)$ berpendapat bahwa pelayanan posyandu yang diberikan baik, sebagian kecil responden sebanyak 5 orang $(13,9 \%)$ berpendapat bahwa pelayanan yang diberikan kurang.

2. Frekuensi Kunjungan ibu balita di posyandu VI Flamboyan Lingkungan Kiring Kelurahan Gedongombo Kecamatan Semanding

Tabel 6 Distribusi Frekuensi Kunjungan Ibu Balita Di

3. Hubungan Pelayanan Posyandu Dengan Kunjungan Ibu Balita Di Posyandu VI Flamboyan Lingkungan Kiring Kelurahan Gedongombo Kecamatan Semanding Tabel 7 Analisis Hubungan Kualitas Pelayanan Posyandu Dengan Frekuensin Kunjungan Ibu Balita Di Posyandu VI Flamboyan Lingkungan Kiring Kelurahan Gedongombo Kecamatan Semanding

\begin{tabular}{ccccc}
\hline \multirow{2}{*}{ No } & Kualitas & \multicolumn{2}{c}{ Frekuensi Kunjungan Ibu Balita } & \multirow{2}{*}{ Total } \\
\cline { 3 - 5 } & Pelayanan & Tidak Rutin & Rutin & n (\%) \\
\cline { 3 - 5 } & Posyandu & $\mathbf{n}(\%)$ & n $(\%)$ & $5(100 \%)$ \\
\hline 1 & Kurang & $5(100 \%)$ & $0(0 \%)$ & $24(100 \%)$ \\
2 & Cukup & $21(87,5 \%)$ & $3(12,5 \%)$ & $7(100 \%)$ \\
3 & Baik & $3(42,9 \%)$ & $4(57,1 \%)$ & $36(100 \%)$ \\
\hline
\end{tabular}

Tabel 7 diatas dapat diketahui bahwa dari $36(100 \%)$ responden didapatkan pelayanan posyandu kurang sebanyak 5 (100\%) responden tidak rutin datang di posyandu. Pada pelayanan posyandu cukup sebanyak $21(87,5 \%)$ responden tidak rutin datang di posyandu dan $3(12,5 \%)$ responden rutin datang di posyandu. Pada pelayanan posyandu baik sebanyak $3(42,9 \%)$ responden tidak rutin datang di posyandu dan 4 $(57,1 \%)$ responden rutin datang di posyandu.
Berdasarkan

distribusi kunjungan ibu balita di posyandu di tinjau dari pelayanan posyandu, nampak bahwa semakin baik pelayanan yang diberikan maka semakin rutin ibu balita dalam mengikuti kegiatan di posyandu. Sebaliknya semakin rendah pelayanan yang diberikan maka semakin tidak aktif kunjungan ibu balita dalam kegiatan di posyandu.

Berdasarkan hasil analisis program SPSS for windows menggunakan uji Koefisien Kontingensi dengan tingkat 
kemaknaan $\alpha=0,05$ didapatkan nilai correlation coefficient $\rho=0,016$ nilai $\rho<\alpha$ maka dapat disimpulkan $\mathrm{H}_{0}$ ditolak dan $\mathrm{H}_{1}$ diterima yang berarti ada hubungan signifikan antara pelayanan posyandu dengan kunjungan ibu balita di Posyandu VI Flamboyan Lingkungan Kiring Kelurahan Gedongombo Kecamatan Semanding Tahun 2019.

\section{PEMBAHASAN}

\section{Kualitas Pelayanan Posyandu di Posyandu VI Flamboyan Lingkungan Kiring Kelurahan Gedongombo Kecamatan Semanding Tahun 2019}

Berdasarkan hasil penelitian menggunakan kuesioner yang diberikan kepada ibu balita yang datang di posyandu VI Flamboyan Lingkungan Kiring Kelurahan Gedongombo Kecamatan Semanding, dari 36 responden menunjukkan bahwa responden yang berpendapat pelayanan posyandu kurang sebanyak 5 orang $(13,9 \%)$, sedangkan pelayanan posyandu baik sebanyak 7 orang $(19,4 \%)$, dan responden yang berpendapat pelayanan posyandu cukup sebanyak 24 orang $(66,7 \%)$. Distribusi jawaban responden dikelompokkan menjadi 3 kategori, yaitu kurang, cukup, dan baik. Jika nilai responden 10-14 masuk kategori kurang, nilai 15-17 masuk kategori cukup, dan nilai 1820 masuk kategori baik.

$$
\text { Pelayanan merupakan }
$$

Kegiatan yang dilakukan untuk meningkatkan kesehatan anak dengan memanfaatkan sarana prasarana yang ada di masyarakat, salah satu contoh yaitu kegiatan Pos Pelayanan Terpadu. Pelayanan juga dapat diartikan sebagai aktivitas/ hasil yang dapat ditawarkan oleh sebuah lembaga kepada pihak lain yang biasanya tidak kasat mata, dan hasilnya tidak dapat dimiliki oleh pihak lain. Pelayanan merupakan aktivitas tambahan diluar tugas pokok (job description) yang diberikan kepada konsumen-pelanggan, nasabah dan sebagainya, serta dirasakan baik sebagai penghargaan maupun penghormatan (Kotler, 2003).

Pada penelitian Fitriani, didapatkan bahwa ketersediaan sarana yang dibutuhkan posyandu menjadi faktor pendorong ibu balita membawa anaknya ke posyandu. Sehingga pelayanan yang kurang tergantung pada ketersediaan sarana dan prasarana.

Faktor lain yang berpengaruh terhadap pelayanan posyandu adalah adanya dorongan dari kader selaku penggerak masyarakat, tidak hanya pada pemberitahuan jadwal saja tapi kemampuan kader untuk menggerakkan masyarakat. Tokoh masyarakat atau agama mempunyai peran tidak hanya mengumumkan jadwal tetapi lebih pada upaya menggerakkan masyarakat.

Data diatas dapat disimpulkan bahwa dengan pelayanan posyandu baik diharapkan ibu balita lebih rutin mengikuti kegiatan posyandu.

\section{Frekuensi Kunjungan Ibu Balita}

Di Posyandu VI Flamboyan Lingkungan Kiring Kelurahan Gedongombo Kecamatan Semanding

Berdasarkan hasil penelitian pada kunjungan ibu balita mengikuti kegiatan di posyandu VI Flamboyan Lingkungan Kiring Kelurahan Gedongombo Kecamatan Semanding Tahun 2019, dari 36 responden menunjukkan sebagian besar ibu balita tidak rutin datang di posyandu sebanyak 29 orang $(80,6 \%)$ dan 
sebagian kecil responden yang rutin berkunjung di posyandu sebanyak 7 orang $(19,4 \%)$. Diketahui bahwa $80,6 \%$ responden tidak rutin datang di posyandu dilihat dari buku Kartu Menuju Sehat (KMS) balita.

Kunjungan ibu balita di posyandu adalah kedatangan ibu balita dalam mengikuti kegiatan posyandu secara rutin setiap bulan dan merupakan salah satu bentuk perilaku kesehatan balita dalam upaya memlihara dan meningkatkan kesehatan secara optimal. Responden yang dikatakan tidak rutin berkunjung di posyandu apabila datang $<12 x$ dalam satu tahun, sedangkan yang dikatakan rutin berkunjung di posyandu apabila datang $12 \mathrm{x}$ dalam satu tahun.

Lawrence Green (1980) mengkaji masalah perilaku manusia dan faktor-faktor yang mempengaruhi, serta cara menindaklanjuti dengan berusaha mengubah, memelihara atau meningkatkan perilaku ke arah yang lebih positif. Kedatangan ibu balita dalam memanfaatkan layanan kesehatan dipengaruhi oleh beberapa faktor yaitu umur, pendidikan, pekerjaan, jarak rumah dari posyandu, serta pelayanan yang diberikan petugas posyandu. Pelayanan posyandu sangat mempengaruhi kunjungan ibu balita datang di posyandu.

Faktor umur sebagaimana terlihat dalam tabel 1 tentang distribusi responden berdasarkan umur ibu balita menunjukkan bahwa sebagian besar responden berumur antara 20-35 Tahun sebanyak 33 $(91,7 \%)$. Hasil tersebut berarti bahwa responden berumur muda paling banyak karena menurut Walgito (2003) umur merupakan salah satu faktor fisiologis. Pada umumnya orang muda sikapnya lebih radikal daripada sikap orang yang lebih tua, sedangkan pada orang dewasa sikapnya lebih moderat.

Faktor pendidikan ibu balita sebagaimana terlihat dalam tabel 5.2 tentang distribusi responden berdasarkan pendidikan ibu balita di posyandu VI Flamboyan Lingkungan Kiring Kelurahan Gedongombo Kecamatan Semanding menunjukkan bahwa sebagian besar responden pendidikan SD sebanyak 18 orang $(50 \%)$. Hal ini sesuai dengan penelitian Ngastiyah (2005) yang menjelaskan bahwa faktor pendidikan menentukan tinggi rendahnya seseorang dalam memahami pengetahuan tentang kegiatan posyandu. Dimana semakin baik pendidikan ibu balita, maka dapat menerima segala informasi dari luar terutama tentang cara pengasuhan anak dan manfaat kegiatan posyandu. Faktor pekerjaan dapat diketahui bahwa sebagian besar responden sebanyak 11 orang $(30,6 \%)$ adalah ibu yang berprofesi sebagai wiraswasta, dan sebagian kecil reponden sebanyak 2 orang $(5,6 \%)$ adalah ibu yang berprofesi sebagai PNS. Hal ini menunjukkan bahwa kunjungan ibu balita tidak teratur disebabkan karena ibu yang bekerja. Menurut bidan setempat ibuibu yang tidak bekerja lebih memperhatikan kesehatan dan pertumbuhan anaknya serta lebih rutin datang di posyandu setiap bulannya daripada ibu-ibu yang bekerja.

Menurut Ismawati (2010) jarak rumah dengan lokasi posyandu yang jauh atau sulit dijangkau merupakan kendala orangtua dalam mengikuti kegiatan posyandu. Jarak rumah yang dekat akan membuat orangtua mudah terjangkau datang di posyandu. 
Faktor terakhir yang mempengaruhi kunjungan ibu balita adalah faktor pelayanan posyandu. Kotler (2003) mengatakan bahwa pelayanan merupakan aktivitas tambahan diluar tugas pokok ( $\mathrm{Job}$ Description) yang diberikan kepada konsumen-konsumen, nasabah dan sebagainya, serta dirasakan baik sebagai penghargaan maupun penghormatan. Jika pelayanan posyandu baik, maka kunjungan ibu balita juga akan baik dan rutin. Tetapi sebaliknya jika pelayanan posyandu kurang baik, maka kunjungan ibu balita untuk datang dalam kegiatan posyandu juga rendah atau tidak rutin.

\section{Hubungan Kualitas Pelayanan \\ Posyandu Dengan Frekuensi \\ Kunjungan Ibu Balita Di \\ Posyandu VI Flamboyan \\ Lingkungan Kiring Kelurahan \\ Gedongombo Kecamatan \\ Semanding Tahun 2019}

Dilihat dari hasil penelitian

yang telah dilaksanakan dari pelayanan posyandu dengan kunjungan ibu balita di posyandu dapat dijelaskan sebagai berikut:

Berdasarkan kuesioner yang diberikan pada responden untuk mengetahui pelayanan posyandu menunjukkan bahwa responden berpendapat pelayanan posyandu kategori kurang sebanyak 5 orang $(13,9 \%)$, sedangkan pelayanan posyandu kategori baik sebanyak 7 orang $(19,4 \%)$, dan mayoritas pelayanan posyandu kategori cukup sebanyak 24 orang $(66,7 \%)$

Data dari survei responden di posyandu VI Flamboyan Lingkungan Kiring Kelurahan Gedongombo Kecamatan Semanding Tahun 2019, dari 36 responden yang tidak rutin datang mengikuti kegiatan posyandu sebanyak 29 orang $(80,6 \%)$, dan responden yang rutin datang mengikuti kegiatan posyandu sebanyak 7 orang $(19,4 \%)$.

Hasil analisa menggunakan program SPSS for windows menggunakan uji Koefisien Kontingensi $\rho=0,016, \rho<\alpha$ maka dapat disimpulkan $\mathrm{H}_{1}$ diterima berarti ada hubungan yang signifikan antara pelayanan posyandu dengan kunjungan ibu balita di posyandu VI Flamboyan Lingkungan Kiring Kelurahan Gedongombo Kecamatan Semanding.

Tabel 7 diatas dapat diketahui bahwa pelayanan posyandu kurang sebanyak 5 orang (100\%) tidak rutin berkunjung di posyandu, pelayanan posyandu cukup sebanyak 21 orang $(87,5 \%)$ tidak rutin berkunjung di posyandu serta pelayanan posyandu cukup sebanyak 3 orang $(12,5 \%)$ rutin berkunjung di posyandu, dan pelayanan posyandu baik sebanyak 3 orang $(42,9 \%)$ tidak rutin berkunjung di posyandu serta pelayanan posyandu baik sebanyak 4 orang $(57,1 \%)$ rutin berkunjung di posyandu. Pelayanan posyandu baik tetapi kunjungan di posyandu tidak rutin disebabkan karena jarak rumah dari posyandu jauh.

Hasil penelitian ini sependapat dengan Kresno (2008) bahwa jarak rumah dengan posyandu yang jauh merupakan kendala dalam mengikuti kegiatan posyandu. Jarak posyandu dengan rumah berpengaruh terhadap perilaku kunjungan ibu balita di posyandu.

Kunjungan ibu balita di posyandu adalah kedatangan mengikuti kegiatan posyandu secara rutin setiap bulan selama satu tahun. Dikatakan rutin bila datang di posyandu $12 x$ dalam satu tahun yaitu pada bulan April 2015 sampai Maret 2019, dan dikatakan tidak rutin bila 
datang di posyandu $<12 x$ dalam satu tahun yaitu pada bulan April 2015 sampai Maret 2019. Manfaat datang di posyandu yaitu antara lain: Memperoleh kemudahan untuk mendapatkan informasi dan pelayanan kesehatan bagi anak balita dan ibu, pertumbuhan anak balita terpantau sehingga tidak menderita gizi kurang atau gizi buruk. Bayi dan anak balita mendapatkan kapsul vitamin A, bayi memperoleh immunisasi lengkap, ibu hamil juga akan terpantau berat badannya dan memperoleh kapsul Vitamin A dan tablet tambah darah serta memperoleh penyuluhan kesehatan yang berkaitan dengan kesehatan ibu dan anak.

Beberapa faktor yang mempengaruhi kunjungan di posyandu menurut Notoatmodjo (2003) yaitu umur, pendidikan, pekerjaan, jarak rumah dari posyandu serta pelayanan yang diberikan oleh petugas posyandu. Pelayanan posyandu yang baik dapat mempengaruhi kunjungan semakin rutin datang di posyandu.

Pada penelitian ini dapat kita ketahui bahwa terdapat hubungan antara pelayanan posyandu dengan kunjungan ibu balita di posyandu VI Flamboyan Lingkungan Kiring Kelurahan Gedongombo Kecamatan Semanding. Dapat disimpulkan bahwa semakin baik pelayanan posyandu yang diberikan kepada masyarakat, maka semakin rutin ibu balita datang di posyandu. Sebaliknya semakin rendah pelayanan posyandu yang diberikan kepada masyarakat, maka semakin tidak rutin ibu balita datang di posyandu.

\section{SIMPULAN DAN SARAN Simpulan}

Dari hasil penelitian yang berjudul "Hubungan Pelayanan
Posyandu Dengan Kunjungan Ibu Balita Di Posyandu VI Flamboyan Lingkungan Kiring Kelurahan Gedongombo Kecamatan Semanding" dapat disimpulkan sebagai berikut:

1) Sebagian besar pelayanan posyandu di posyandu VI Flamboyan Lingkungan Kiring Kelurahan Gedongombo Kecamatan Semanding cukup, hal ini disebabkan oleh setengah dari responden menilai petugas tanggap dalam melakukan tugas masing-masing dan setengah dari responden menilai petugas peduli saat mengingatkan jadwal buka posyandu.

2) Sebagian besar kunjungan ibu balita di posyandu VI Flamboyan Lingkungan Kiring Kelurahan Gedongombo Kecamatan Semanding tidak rutin, hal ini disebabkan oleh faktor umur, pendidikan, pekerjaan, jarak rumah dari posyandu, serta pelayanan yang diberikan oleh posyandu.

3) Setelah dilakukan uji statistik SPSS for windows diperoleh hasil bahwa terdapat hubungan antara pelayanan posyandu dengan kunjungan ibu balita di posyandu VI Flamboyan Lingkungan Kiring Kelurahan Gedongombo Kecamatan Semandingtahun 2019.

\section{SARAN}

Dari hasil penelitian yang telah dilakukan maka saran yang diberikan oleh peneliti antara lain:

1) Bagi Pengembangan Ilmu Pengetahuan

Sebagai bahan pertimbangan untuk lebih mengembangkan ilmu khususnya di bidang keperawatan komunitas dan untuk peneliti selanjutnya diharapkan dapat 
mengkaji lebih dalam tentang faktor-faktor lain yang berkaitan dengan kunjungan ibu balita atau menggunakan variabel lain yang belum diteliti.

2) Bagi Profesi Keperawatan Meningkatkan penyuluhan kepada ibu balita untuk mengetahui manfaat mengikuti kegiatan posyandu balita sehingga dapat mendorong dan mengubah perilaku ibu balita untuk datang dan mengikuti kegiatan di posyandu secara rutin.

3) Bagi Institusi

Petugas posyandu sebaiknya mensosialisasikan dan memotivasi ibu balita tentang pentignya manfaat datang di posyandu.

\section{DAFTAR PUSTAKA}

Arikunto, S. 2006. Prosedur Penelitian Suatu Pendekatan Praktek, Edisi 5. Jakarta: Rhineka Cipta.

Anzwar. 1998. Sikap Manusia Dan Teori Pengukurannya, Edisi 2. Jakarta: Pustaka Belajar.

Becker. 1979. Pendidikan dan Perilaku Kesehatan. Jakarta: Rineka Cipta.

Benyamin Bloom. 1908. Pendidikan dan Perilaku Kesehatan. Jakarta: Rineka Cipta.

Cahyo Ismawati, dkk, S. 2010. Posyandu dan Desa Siaga. Yogyakarta: Nuha Medika.

Dinas Kesehatan Kabupaten Tuban. 2015. Profil Kesehatan Kabupaten Tuban Tahun 2015. Tuban: Dinas Kesehatan Kabupaten Tuban.
Dinas Kesehatan Provinsi Jawa Timur. 2012. Profil Kesehatan Provinsi Jawa Timur Tahun 2012. Jawa Timur: Dinas Kesehatan Provinsi Jawa Timur.

Effendy, Nasrul. 1998. Dasar-Dasar Keperawatan Kesehatan Masyarakat, E/2. Jakarta: EGC.

Green, Lawrence. 1980. Health Behaviour Education, A Diagnostic Approuch. The John Hopkins University. Mayfield Publishing Co.

Elizabeth T. Anderson, Judith MC Farlance. 2007. Keperawatan Komunitas. Yogyakarta: Nuha Medika.

Hasanbasri. 2007. Manajemen Puskesmas dan Partisipasi Masyarakat Dalam Kegiatan Posyandu. $\quad$ http://Irckmpk.ugm.ac.id

Http://gizi.depkes.go.id, diakses 28 Desember 2015

Http://www.Promkes.depkes.go.id, diakses 15 Desember 2015

Indonesia. Kementerian Kesehatan RI. Buku Kesehatan Ibu dan Anak. Jakarta: Kementerian Kesehatan dan JICA (Japan International Cooperation Agency. 1997.

Indonesia. Kementerian Kesehatan RI. Sekretariat Jendral Profil Kesehatan Indonesia Tahun 2014. Jakarta: Kementerian Kesehatan RI. 2015 
http://www.kemkes.go.id, diakses 25 November 2015

Indonesia. Kementerian Kesehatan RI. Sekretariat Jendral Profil Kesehatan Indonesia Tahun 2013. Jakarta: Kementerian Kesehatan RI. 2014 http://www.kemkes.go.id, diakses 25 November 2015

Intanghina. 2008. Peran serta ibu balita dalam kegiatan penimbangan.

Http://Intanghina.wordpress.co $\underline{\mathrm{m}}$, diakses 19 Januari 2019

Ismawati, C.S. 2010. Pos Pelayanan Terpadu Dan Desa Siaga. Yogyakarta: Nuha Medika

Kirschat. 1980 dalam Lawrence Green. 1980. Health Behaviour Education, A Diagnostic Approuch. The John Hopkins University. Mayfield Publishing Co.

Kotler. 2003. Manajemen Pemasaran. Jakarta: Prenhallindo.

Kresno, M. 2008. Laporan Penelitian Studi Pemanfaatan Posyandu Di Kelurahan Cipinang Kec. Jatinegara Kodya Jakarta Timur. Jakarta: FKM Universitas Indonesia.

MARS, Dr.H.Boysubirosa

Sabarguna. 2009. Pembangunan Posyandu, Peningkatan Pendapatan, Pengolahan sampah juga seni dan pariwisata dalam rangka PEMBANGUNAN

MASYARAKAT DESA. Jakarta: Sagung Seto.
Mehra dan Burhan. 2009 dalam Sobur. 1964. Pendidikan Kesehatan dalam Keperawatan. Jakarta: EGC.

Mucchielli. 1980 dalam Lawrence green. 1980. Health Behaviour Education, A Diagnostic Approuch. The John Hopkins University. Mayfield Publishing Co.

Muninjaya. 2014. Manajemen Mutu Pelayanan Kesehatan, Edisi 2. Jakarta: EGC

Ngastiyah. 2005. Perawatan Anak Sakit Edisi 2. Jakarta: EGC

Niven, N. 2002. Kesehatan Pengantar Untuk Perawat Dan Profesional Kesehatan Lain. Jakarta:EGC

Notoatmodjo, S. 2005. Metodologi Penelitian Kesehatan. Jakarta: Rineka Cipta.

Novitasari, N. 2015. Bimbingan Kader Posyandu Dengan Keaptuhan Kunjungan Ibu Balita Di Posyandu.

Nursalam. 2013. Metodologi Penelitian Ilmu Keperawatan Pendekatan Klinis, Edisi 3. Jakarta: Salemba Medika.

Pamungkas, L. 2008. Hubungan Antara Faktor Pengetahuan, Sikap Dan Kepercayaan Dengan Perilaku Ibu Berkunjung Ke Posyandu III Kelurahan Grabagan Kecamatan Grabagan Kabupaten Magelang. 
Pranata, Pratiwi, dan Rahanto. 2011. Pemberdayaan Masyarakat Di Bidang Kesehatan, Gambaran Peran Kader Posyandu Dalam Upaya Penurunan Angka Kematian Ibu dan Bayi Di Kota Manado dan Palangkaraya. Diakses dari http://journal.litbang.depkes.go .id/index.php/hsr/article/ViewF ile/2321/2164 pada 25

November 2015

Prof.Dr. Soekidjo Notoatmodjo. 2003. Pendidikan dan Perilaku Kesehatan. Jakarta: Rineka Cipta.

Puskesmas Wire. 2019. Jumlah Balita Yang Ditimbang Setiap Lingkungan Kelurahan Gedongombo Tahun 20142015. Tuban: Seksi Gizi Puskesmas Wire Kabupaten Tuban.

R. Fallen dan R. Budi Dwi K. 2010. "Catatan Kuliah" KEPERAWATAN

KOMUNITAS. Yogyakarta: Nuha Medika.

Rogers. 1974 dalam Notoatmodjo, Soekidjo. 2003. Pendidikan dan Perilaku Kesehatan. Jakarta: Rineka Cipta.

Ronsenstock, dkk. 1980 dalam Lawrence Green. 1980. Health Behaviour Education, A Diagnostic Approuch. The John Hopkins University. Mayfield Publishing Co.
Santoso, Slamet. 2009. Pendidikan dan Perilaku Kesehatan. Jakarta: Rineka Cipta.

Sobur. 2009. Pendidikan Kesehatan Dalam Keperawatan. Jakarta: EGC

SR.Dr.Hj. Hardiko. 2007. Mengawal Pertumbuhan si buah hati. Karanganom: Cempaka Putih.

Sumini. 2013. Hubungan Motivasi Dengan Keaktifan Ibu Membawa Balita Ke Posyandu Kelurahan Tonata Kecamatan Ponorogo Kabupaten Ponorogo.

Syakira, Tentang Posyandu. http://syakira-blogblogspot.com, diakses 19 Januari 2015

Syahrir, L. O., H, A. F., \& Latief, B. 2013. Faktor-Faktor Yang Berhubungan Dengan Kunjungan Ibu Yang Mempunyai Balita Ke Posyandu Wilayah Kerja Puskesmas Tamalanrea Makassar.

Trisnawati. 2011. Hubungan Persepsi Ibu Tentang Posyandu Dengan Perilaku Kunjungan Balita Ke Posyandu Mawar Di Dusun Soragan Ngestiharjo Kasihan Bantul Yogyakarta Tahun 2011. Skripsi (Tidak Diterbitkan). Program Studi Ilmu Keperawatan. Sekolah Tinggi Ilmu Kesehatan Aisyiyah Yogyakarta. 
Triwibowo. 2012. Perijinan dan

Akreditasi Rumah Sakit.

Yogyakarta: Nuha Medika.

Wahit Iqbal Mubarok dan Nurul

Chayatin. 2011. Ilmu

Keperawatan Komunitas 1. Jakarta: Salemba Medika.

Walgito, Bimo. 2003. Psikologi Sosial Suatu Pengantar. Yogyakarta: Andi, Hal: 111118,135

World Health Organization. 2003. A Framework For Community Health Nursing Education. Http://www.search.who.int/Lin kFiles/Regional_Initiatives_SE A-NUR-467.pdf diakses 25 $\underline{\text { November } 2015}$

Zulkifli. 2003. Posyandu dan Kader Kesehatan, Fakultas Kesehatan Masyarakat. Universitas Sumatra Utara. Http://cpddokter.com ,diakses 19 Januari 2015 